JPSCR: Journal of Pharmaceutical Science and Clinical Research, 2020, 02, 84-96

DOI: $10.20961 /$ jpscr.v5i2.44070

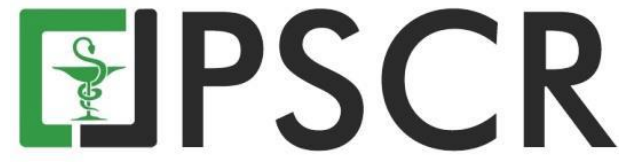

\title{
Aktivitas Antioksidan Kombinasi Fraksi Metanol Virgin Coconut Oil dan Madu Kele Bali dengan Metode DPPH (2,2-diphenyl-1-picrylhidrazyl)
}

\author{
Ni Putu Eka Leliqia*, I Ketut Gede Gilang Gama Harta, A.A. Bagus Yoga Saputra, Pande \\ Made Nova Armita Sari dan Ni Putu Linda Laksmiani
}

\author{
Program Studi Farmasi, Fakultas MIPA, Universitas Udayana, J1. Raya Kampus Unud, Jimbaran, Kabupaten \\ Badung, Bali, Indonesia, 80361 \\ *email korespondensi: eka_leliqia@unud.ac.id
}

Received 29 August 2020, Accepted 03 October 2020, Published 30 October 2020

\begin{abstract}
Abstrak: Virgin coconut oil (VCO) dan madu telah banyak digunakan sebagai bahan baku sediaan topikal untuk perawatan kulit. Salah satu khasiat yang telah terbukti adalah aktivitas antioksidannya. Namun efek VCO dan madu sebagai antioksidan umumnya masih dibuktikan dalam bentuk bahan tunggal tidak dalam bentuk kombinasi keduanya. Pengujian aktivitas antioksidan dengan metode DPPH memerlukan sampel uji yang bersifat polar. Fraksi metanol dari VCO dan madu telah diketahui bersifat polar. Tujuan penelitian ini adalah menentukan kombinasi fraksi metanol VCO dan madu kele Bali yang memberikan aktivitas antioksidan paling kuat. VCO dan madu kele Bali diperoleh dari Desa Aan, Bali. Skrining fitokimia fraksi metanol VCO dan madu kele Bali ditentukan ditentukan dengan metode yang sesuai. Aktivitas antioksidan $\left(\mathrm{IC}_{50}\right)$ fraksi metanol VCO, madu kele Bali, dan kombinasi keduanya ditentukan dengan metode DPPH. Terdapat 5 kombinasi kedua bahan tersebut yang diuji. Data dianalisis menggunakan ANOVA oneway-LSD dengan taraf kepercayaan 95\%. Fraksi metanol VCO mengandung flavonoid dan tanin, sedangkan madu kele Bali mengandung saponin, fenol, flavonoid dan steroid/triterpenoid. Fraksi metanol VCO dan madu kele Bali memiliki aktivitas antioksidan dengan nilai IC $\mathrm{I}_{50}$ berturut-turut sebesar 7,20 $\pm 0,23 \mathrm{mg} / \mathrm{mL}$ dan $14,56 \pm 0,25 \mathrm{mg} / \mathrm{mL}$. Perbandingan jumlah kombinasi fraksi metanol VCO dan madu kele Bali berpengaruh secara bermakna terhadap aktivitas antioksidannya $(\mathrm{p}<0,05)$. Kombinasi $0,0063 \mathrm{~g}$ fraksi metanol VCO dan $1 \mathrm{~g}$ madu kele Bali menunjukkan aktivitas antioksidan paling kuat ( $\mathrm{IC}_{50} 8,50 \pm 0,17 \mathrm{mg} / \mathrm{mL}$ ). Fraksi metanol VCO dan madu kele Bali serta kombinasinya tergolong antioksidan lemah, namun terjadi peningkatan aktivitas antioksidan yang bermakna pada kombinasi ini dibandingkan madu kele Bali tunggal $(\mathrm{p}<0,05)$.
\end{abstract}

Kata kunci: Antioksidan; DPPH; Fraksi Metanol; Kombinasi; Madu Kele Bali; Virgin coconut oil

Abstract. Antioxidant Activity of Methanol Fraction of Virgin Coconut Oil and Balinese Kele Honey Combination using DPPH (2,2-diphenyl-1-picrylhidrazyl) Method. Virgin coconut oil (VCO) and honey have been widely used as raw materials for skincare dosage. One of its proven properties is its antioxidant activity. However, the effect of VCO and honey as antioxidants is generally still proven in the form of a single ingredient, not a combination of the two. Testing the antioxidant activity using the DPPH method requires a polar test sample. The methanol fraction of VCO and honey are known to be polar. The aim of the study was to determine the combination of methanol fraction of VCO and Balinese kele honey which provided the strongest antioxidant activity. VCO and Balinese kele honey were obtained from Aan Village, Bali. Phytochemical screening of the methanol fraction of VCO and Balinese kele honey were determined by the appropriate method. The antioxidant activity $\left(\mathrm{IC}_{50}\right)$ of the methanol fraction of VCO, Balinese kele honey, and the combination of both were determined 
by the DPPH method. There were 5 combinations of the two ingredients that were tested. Data were analyzed using ANOVA one way-LSD with a confidence level of 95\%. The methanol fraction of VCO contains flavonoids and tannins, while Balinese kele honey contains saponins, phenols, flavonoids and steroids/triterpenoids. The methanol fraction of VCO and Balinese kele honey had antioxidant activity with $\mathrm{IC}_{50}$ values of $7.20 \pm 0.23 \mathrm{mg} / \mathrm{mL}$ and $14.56 \pm 0.25 \mathrm{mg} / \mathrm{mL}$, respectively. Comparison of the combined amount of methanol fraction of VCO and Balinese kele honey significantly affected its antioxidant activity $(\mathrm{p}<0.05)$. The combination with $0.0063 \mathrm{~g}$ of methanol fraction of $\mathrm{VCO}$ and $1 \mathrm{~g}$ of Balinese kele honey revealed the strongest antioxidant activity $\left(\mathrm{IC}_{50} 8.50 \pm 0.17 \mathrm{mg} / \mathrm{mL}\right.$ ). The methanol fraction of $\mathrm{VCO}$ and Balinese kele honey and their combination were classified as weak antioxidants, but there was a significant increase in antioxidant activity in this combination compared to Balinese kele honey alone ( $\mathrm{p}$ $<0.05)$.

Keywords: Antioxidant; DPPH; Methanol Fraction; Combination; Balinese Kele Honey; Virgin coconut oil

\section{Pendahuluan}

Minyak kelapa dan madu telah diketahui banyak dimanfaatkan secara empiris dalam berbagai ramuan obat (Sari et al, 2017; Diba et al, 2018). Minyak kelapa yang dimurnikan atau virgin coconut oil (VCO) merupakan salah satu bahan baku sediaan perawatan kulit yang mulai banyak diminati. Kombinasi VCO dan madu digunakan untuk perawatan kulit wajah khususnya menghambat proses penuaan. Proses penuaan dapat dihambat oleh antioksidan dengan mengendalikan reaktivitas radikal bebas (Winarsi et al, 2013). Kedua bahan ini telah dibuktikan memiliki aktivitas antioksidan dan dapat menghambat penuaan dini pada kulit (Eder et al, 2006; Setiaji dan Prayugo, 2006; Malik et al, 2019). Penelitian yang dilakukan oleh Marina et al (2009), membuktikan VCO yang diuji dalam bentuk fraksi metanolnya memiliki nilai $\mathrm{IC}_{50}$ sebesar $1,24 \mathrm{mg} / \mathrm{mL}$. Sedangkan madu yang dihasilkan dari lebah tanpa sengat memiliki nilai $\mathrm{IC}_{50}$ sebesar $3,736 \mathrm{mg} / \mathrm{mL}$ (Sumarlin et al, 2015). Pengujian aktivitas antioksidan kedua sampel tersebut dilakukan dengan metode DPPH, namun dalam preparasinya VCO memiliki perlakuan yang lebih rumit dibandingkan madu. VCO memerlukan proses fraksinasi terlebih dahulu sehingga diperoleh fraksi metanol yang siap untuk diuji (Marina et al, 2009; Wallace, 2018).

Kandungan kimia yang terdapat di dalam bahan alami memegang peranan penting terhadap aktivitas antioksidannya. Asal pengambilan sampel atau letak geografis merupakan salah satu faktor yang dapat berpengaruh terhadap jenis dan jumlah kandungan kimia yang terdapat dalam suatu bahan alami yang memiliki aktivitas farmakologi. Pada VCO, khususnya pada buah kelapa (bahan baku VCO), dengan proses pengolahan yang sama, VCO yang dibuat dari buah kelapa dari pohon yang tumbuh di lokasi berbeda memiliki karakteristik dan kandungan yang berbeda (Novarianto dan Tulalo, 2007). Hal yang sama juga berlaku untuk 
madu. Letak geografis dari koloni lebah dapat mempengaruhi karakteristik madu yang dihasilkan. Perbedaan letak geografis akan mempengaruhi sumber nektar (flora) hingga keadaan lingkungan di sekitar koloni lebah. Perbedaan tersebut menyebabkan perbedaan karakteristik dan kandungan madu antara satu tempat dengan tempat lainnya (Parwata et al, 2010; Chayati dan Miladiyah, 2014; Chan et al, 2017).

Salah satu daerah penghasil VCO dan madu kele Bali adalah Desa Aan, Kecamatan Banjarangkan, Klungkung, Bali. VCO diperoleh dari kebun kelapa di desa Aan yang dibuat dengan pemanasan terkendali. Madu kele diperoleh dari hasil peternakan lebah kele di desa setempat dengan pohon kopi sebagai salah satu sumber nektarnya. Madu kele merupakan madu yang dihasilkan oleh lebah tanpa sengat yang termasuk dalam genus Trigona yang salah satu spesiesnya adalah Trigona laeviceps. VCO yang dalam penelitian ini digunakan dalam bentuk fraksi metanolnya dan madu kele Bali dari Desa Aan Bali belum ada yang meneliti aktivitas antioksidannya termasuk aktivitas dari kombinasi kedua bahan tersebut dengan berbagai variasi komposisi. Pada beberapa penelitian, penggunaan kombinasi dari dua jenis antioksidan memberikan aktivitas antioksidan yang lebih tinggi dibandingkan bahan tunggalnya (Aftab and Vieira, 2010; Wicaksono dan Ulfah, 2017; Harningsih dan Wimpy, 2018). Berdasarkan hal tersebut, maka dilakukan penelitian yang bertujuan untuk menentukan aktivitas antioksidan fraksi metanol VCO dan madu kele Bali dalam bentuk tunggal serta kombinasinya menggunakan metode DPPH. Diharapkan hasil penelitian ini dapat memberikan informasi terkait kombinasi fraksi metanol VCO dan madu kele Bali dengan komposisi yang paling kuat aktivitas antioksidannya sehingga dapat dijadikan bahan pertimbangan dalam pengembangan produk sediaan topikal untuk perawatan kulit.

\section{Bahan dan Metode}

\subsection{Bahan penelitian}

Virgin coconut oil dan Madu kele diperoleh dari daerah Banjar Petapan, Desa Aan, Kecamatan Banjarangkan, Kabupaten Klungkung, Provinsi Bali. Bahan kimia yang digunakan adalah aseton, asam borat, asam oksalat, asam asetat anhidrat, asam sulfat, asam klorida, eter, metanol, dan DPPH (2,2-diphenyl-1-picrylhidrazyl) dengan derajat p.a. (Merck; Darmstadt, Jerman). Selain itu digunakan bahan lain yaitu vitamin C (pharmagrade), n-heksana (Bratachem ${ }^{\circledR}$ ), akuades (Bratachem $\left.{ }^{\circledR}\right)$, larutan besi (III) klorida $\mathrm{FeCl}_{3}$, gelatin, Dragendorff $\mathrm{P}$, Mayer P, dan Bouchardat P.

\subsection{Metode penelitian}

2.2.1. Preparasi fraksi metanol VCO dan madu kele Bali 
Virgin coconut oil difraksinasi dengan metode ekstraksi cair-cair menggunakan dua pelarut tidak bercampur yaitu n-heksana dan metanol 60\%. VCO ditimbang $10 \mathrm{~g}$ dan dilarutkan dengan 25 mL n-heksana. Larutan VCO dimasukkan ke dalam corong pisah dan ditambahkan $20 \mathrm{~mL}$ metanol 60\%. Corong pisah digojog dan didiamkan hingga terbentuk dua fase yang tidak saling campur. Fraksi metanol VCO dikumpulkan kemudian pelarut diuapkan hingga diperoleh fraksi kering sebanyak 0,021 gram. Rendemen fraksi metanol VCO dihitung untuk digunakan dalam menentukan perbandingan kombinasi fraksi metanol dan madu kele Bali. Madu kele Bali disaring menggunakan kertas saring Whatman nomor 20. Filtrat disimpan di dalam wadah tertutup rapat pada suhu kamar.

\subsubsection{Skrining fitokimia fraksi metanol VCO dan madu kele Bali}

Pengujian skrining fitrokimia dari fraksi metanol VCO dan madu kele Bali yang dilakukan meliputi uji saponin, alkaloid, fenol, flavonoid, tanin, dan steroid/triterpenoid sesuai dengan prosedur yang tertera pada literatur acuan. Uji saponin ditentukan dengan menggunakan uji Forth (Depkes RI, 1995). Uji alkaloid dilakukan dengan menggunakan pereaksi pengendapan Dragendorff, Mayer, dan Bouchardat (Depkes RI, 1989). Fenol diuji dengan menggunakan pereaksi $\mathrm{FeCl}_{3}$ (Robinson, 1991). Flavonoid ditentukan dengan uji Wilson-Tauböck (Depkes RI, 1995). Uji tanin dilakukan dengan reaksi pengendapan menggunakan larutan gelatin (Harborne, 1987). Uji steroid/triterpenoid dilakukan dengan menggunakan uji LiebermannBourchard (Depkes RI, 1995).

2.2.3. Penentuan aktivitas antioksidan vitamin C, fraksi metanol VCO, madu kele Bali dan kombinasinya

a. Preparasi sampel uji untuk uji aktivitas antioksidan

Larutan 0,4 mM DPPH disiapkan untuk digunakan sebagai reagen dalam pengujian aktivitas antioksidan. Larutan stok vitamin C, fraksi metanol VCO, dan madu kele Bali disiapkan dengan menimbang sejumlah bahan kemudian dilarutkan dengan metanol pa. Kemudian dibuat seri konsentrasi (6 konsentrasi) untuk menentukan persen penghambatan DPPH. Larutan kombinasi fraksi metanol VCO dan madu kele Bali dibuat dengan perbandingan seperti tertera pada Tabel 1. Perbandingan kedua bahan tersebut ditentukan berdasarkan perbandingan VCO dan madu kele Bali. Penyetaraan jumlah fraksi metanol VCO dari bobot VCO ditentukan berdasarkan nilai rendemennya dari proses fraksinasi. Dari hasil fraksinasi diperoleh rendemen fraksi metanol sebesar 0,21\% dan fraksi n-heksana sebesar 99,70\%. Madu kele dan fraksi metanol VCO dicampur homogen kemudian masing-masing kombinasi dibuat larutan seri konsentrasi (6 konsentrasi) untuk penentuan persen penghambatan DPPH. 


\section{b. Uji Aktivitas Antioksidan dengan Metode DPPH}

Larutan DPPH sebanyak $1 \mathrm{~mL}$ dimasukkan ke dalam botol vial kemudian ditambahkan 2 $\mathrm{mL}$ metanol p.a. Larutan ini digunakan sebagai larutan kontrol DPPH. Untuk sampel uji (vitamin C, fraksi metanol VCO, madu kele Bali, dan berbagai kombinasi keduanya), larutan DPPH sebanyak $1 \mathrm{~mL}$ dimasukkan ke dalam botol vial dan ditambahkan dengan $1 \mathrm{~mL}$ berbagai konsentrasi larutan uji. Kemudian ditambahkan $1 \mathrm{~mL}$ metanol p.a. Semua larutan tersebut digojog hingga homogen kemudian diinkubasi selama 45 menit. Larutan yang telah diinkubasi dibaca serapannya dengan menggunakan spektrofotometer visibel (UV-SHIMADZHU®) pada panjang gelombang maksimum $517 \mathrm{~nm}$. Setiap pengujian dilakukan replikasi sebanyak 6 kali.

Tabel 1. Bobot penimbangan VCO dan madu kele Bali untuk larutan uji kombinasi. *Bobot fraksi metanol VCO untuk kombinasi 1 diperoleh dari rendemen fraksi metanol $\mathrm{x}$ bobot VCO $(\mathrm{g})=0,21 \%$ x 5 gram $=0,0105$ gram. Perhitungan jumlah fraksi metanol VCO pada kombinasi lainnya disesuaikan dengan bobot VCO dalam kombinasi.

\begin{tabular}{cccc}
\hline $\begin{array}{c}\text { Variasi } \\
\text { Kombinasi }\end{array}$ & $\begin{array}{c}\text { Bobot Fraksi } \\
\text { Metanol VCO }(\mathbf{g})\end{array}$ & $\begin{array}{c}\text { Bobot Madu Kele } \\
\text { Bali }(\mathbf{g})\end{array}$ & $\begin{array}{c}\text { Perbandingan } \\
\text { VCO: Madu Kele Bali (b/b) }\end{array}$ \\
\hline Kombinasi 1 & $0,0105^{*}$ & 1 & $5: 1$ \\
Kombinasi 2 & 0,0084 & 2 & $4: 2$ \\
Kombinasi 3 & 0,0063 & 3 & $3: 3$ \\
Kombinasi 4 & 0,0042 & 4 & $2: 4$ \\
Kombinasi 5 & 0,0021 & 5 & $1: 5$ \\
\hline
\end{tabular}

Aktivitas antioksidan ditentukan berdasarkan nilai $\mathrm{IC}_{50}$ yang dihitung menggunakan persamaan regresi linear dengan sumbu x adalah larutan uji (vitamin $\mathrm{C}$, fraksi metanol VCO, madu kele Bali, dan berbagai kombinasi keduanya), sedangkan sumbu y adalah \%IC. Persen inhibition concetration (\% IC) dapat dihitung dengan persamaan 1.

$$
\% \mathrm{IC}=\left(\frac{\text { absorbansi larutan kontrol }- \text { absorbansi larutan blanko })- \text { absorbansi larutan uji } \times 100 \%}{\text { absorbansi larutan kontrol }}\right.
$$

Persamaan 1. Perhitungan persentase inhibition concentration (\%IC) pada uji aktivitas antioksidan

\subsubsection{Analisis hasil}

Data berupa nilai $\mathrm{IC}_{50}$ yang diperoleh dianalisis secara deskriptif dan statistik. Kemampuan antioksidan dikatagorikan menjadi 4 yaitu antioksidan kuat dengan nilai $\mathrm{IC}_{50}$ $<0,05 \mathrm{mg} / \mathrm{mL}$, antioksidan kuat dengan nilai $\mathrm{IC}_{50} 0,05-0,1 \mathrm{mg} / \mathrm{mL}$, antioksidan sedang dengan nilai $\mathrm{IC}_{50} 0,1-0,15 \mathrm{mg} / \mathrm{mL}$, dan antioksidan lemah dengan nilai $\mathrm{IC}_{50}>0,15 \mathrm{mg} / \mathrm{mL}$ (Thamrin et $a l, 2016)$. Aktivitas antioksidan kombinasi yang paling kuat ditentukan berdasarkan nilai $\mathrm{IC}_{50}$ terkecil. Data $\mathrm{IC}_{50}$ vitamin $\mathrm{C}$, fraksi metanol VCO, madu kele Bali, serta berbagai kombinasi fraksi metanol VCO dan madu kele Bali dianalisis secara statistik menggunakan ANOVA one- 
way, dilanjutkan dengan uji posthoct LSD dengan taraf kepercayaan 95\%. Perbedaan bermakna dinyatakan dengan nilai $\mathrm{p}<0,05$.

\section{Hasil dan Pembahasan}

\subsection{Preparasi fraksi metanol VCO dan madu kele Bali}

Preparasi fraksi metanol VCO dan madu kele Bali bertujuan untuk menyiapkan sampel sedemikian rupa sehingga sampel siap dilakukan uji yang diinginkan. Preparasi VCO dilakukan dengan memfraksinasi VCO menggunakan pelarut nonpolar dan polar. Menurut Wallace (2018), penelitian terhadap VCO tidak dapat dilakukan uji secara langsung karena terdapat berbagai macam asam lemak dalam jumlah yang banyak. Berdasarkan hal tersebut, VCO pada penelitian ini dilakukan preparasi untuk memudahkan pendeteksian senyawa dalam uji skrining fitokimia dan pegujian aktivitas antioksidannya. Proses fraksinasi dilakukan menggunakan pelarut n-heksana dan metanol 60\%. Terdapat perbedaan tingkat kepolaran antara n-heksana dan metanol 60\%. Menurut Marina et al (2009) serta Nevin and Rajamohan (2004), pemisahan senyawa polar di dalam VCO dari asam lemak (senyawa nonpolar) dapat dilakukan dengan memfraksinasi sampel uji menggunakan metanol 60\%. Apabila ditinjau dari konstanta dielektriknya (n-heksana $=1,89$; metanol $60 \%=50,96$ ), n-heksana dikategorikan sebagai pelarut nonpolar sedangkan metanol 60\% dikategorikan sebagai pelarut polar (Martin et al, 1993; Rozi et al, 2018). Proses fraksinasi akan memisahkan senyawa-senyawa yang berada di dalam VCO berdasarkan tingkat kepolarannya (like dissolve like). Senyawa fitokimia yang bersifat nonpolar akan tertarik ke dalam fase n-heksana (fraksi n-heksana) sedangkan senyawa yang bersifat polar akan tertarik ke dalam fase metanol (fraksi metanol). Fraksi metanol yang didapatkan berupa serbuk kering sedangkan fraksi n-heksana berbentuk cairan. Hal ini dikarenakan, fraksi n-heksana mengandung lemak tak jenuh dalam jumlah besar.

Tabel 2. Hasil skrining fitokimia fraksi metanol VCO dan madu kele Bali.

\begin{tabular}{|c|c|c|c|}
\hline Golongan Senyawa & Metode Pengujian & Fraksi Metanol VCO & Madu Kele Bali \\
\hline Saponin & $\begin{array}{c}\text { Uji Forth } \\
\text { Uji dengan Pereaksi }\end{array}$ & Negatif & Positif \\
\hline Alkaloid & $\begin{array}{c}\text { Dragendorff, Mayer,dan } \\
\text { Bouchardat }\end{array}$ & Negatif & Negatif \\
\hline Fenol & $\mathrm{Uji} \mathrm{FeCl}_{3}$ & Negatif & Positif \\
\hline Flavonoid & Uji Wilson-Tauböck & Positif & Positif \\
\hline Tanin & Uji Gelatin & Positif & Negatif \\
\hline Steroid/triterpenoid & Uji Liebermann-Bourchard & Negatif & Positif \\
\hline
\end{tabular}

\subsection{Hasil skrining fitokimia fraksi metanol VCO dan madu kele Bali}

Hasil pengamatan pada skrining fitokimia fraksi metanol VCO dan madu kele Bali dapat dilihat pada Tabel 2. Fraksi metanol VCO positif mengandung flavonoid dan tanin. Sedangkan 
madu kele Bali mengandung senyawa golongan saponin, fenol, flavonoid, dan steroid/triterpenoid. Terdapat perbedaan hasil skrining fitokimia madu pada penelitian ini dibandingkan hasil penelitian Sumarlin et al (2015). Pada penelitian tersebut ditemukan adanya alkaloid dan tanin. Perbedaan kandungan antar madu bisa disebabkan karena faktor letak geografis dan sumber nektar (Parwata et al, 2010; Chayati dan Miladiyah, 2014; Kek et al, 2014; Chan et al, 2017).

\subsection{Aktivitas antioksidan}

Vitamin C, fraksi metanol VCO, madu kele Bali, serta kombinasi fraksi metanol VCO madu kele dan madu kele Bali diuji aktivitas antioksidannya dengan metode DPPH. Prinsip pengukuran aktivitas antioksidan dengan menggunakan metode DPPH yaitu adanya penangkapan atom $\mathrm{H}$ dari senyawa antioksidan oleh radikal bebas (DPPH) yang menyebabkan radikal bebas tersebut berubah menjadi nonradikal. Perubahan struktur DPPH dari radikal bebas menjadi bentuk nonradikalnya dapat dilihat pada Gambar 1. Aktivitas antioksidan ditunjukkan dengan hilangnya warna ungu pada larutan uji. Hal ini terjadi karena antioksidan menyebabkan DPPH tereduksi. Perubahan warna tersebut diukur dengan spektrofotometri UV-Vis pada panjang gelombang maksimalnya (Lukitaningsih, 2009).

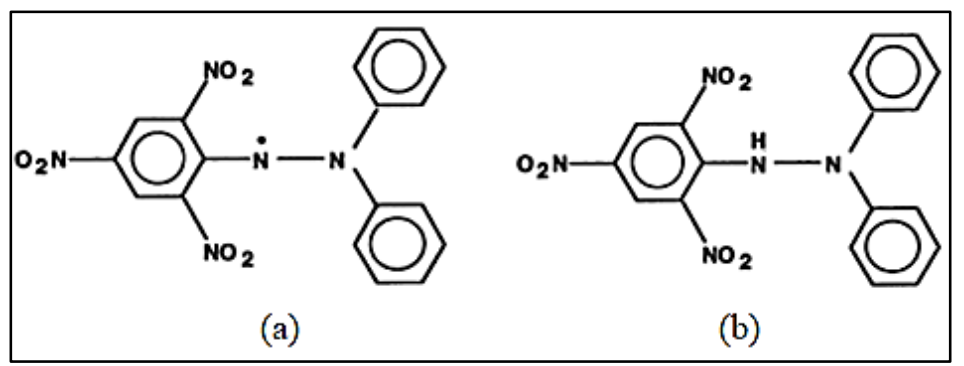

Gambar 1. Perubahan struktur DPPH dari radikal bebas (a) menjadi bentuk nonradikalnya (b) (Molyneux, 2004).

Penelitian diawali dengan pengukuran absorbansi larutan kontrol DPPH. Nilai absorbansi larutan kontrol DPPH ini diperlukan dalam perhitungan persen inhibisi radikal DPPH sesuai dengan persamaan 1. Berdasarkan persamaan tersebut, penurunan absorbansi yang diakibatkan senyawa antioksidan dalam sampel akan dibandingkan dengan absorbansi larutan kontrol DPPH. Kemudian, untuk mendapatkan persentase perubahan atau peredaman radikal DPPH maka nilai penurunan absorbansi oleh antioksidan akan dibandingkan dengan nilai absorbansi kontrol DPPH yang menunjukkan jumlah radikal DPPH awal. Persentase perubahan atau peredaman radikal DPPH dikenal dengan nilai persen inhibisi atau \% IC (percentage inhibition).

Nilai \%IC masing-masing sampel uji ditentukan dengan menggunakan enam titik pada konsentrasi yang berbeda. Semakin banyak titik yang digunakan maka linieritas kurva yang terbentuk dapat memberikan data $\mathrm{IC}_{50}$ yang lebih tervalidasi (Gandjar dan Rohman, 2012). Pada 
pengujian aktvitas antioksidan, VCO tidak dapat diuji secara langsung menggunakan DPPH, sedangkan madu kele Bali dapat diuji secara langsung. VCO mengandung berbagai macam asam lemak dalam jumlah banyak dan polaritas VCO yang cenderung nonpolar menyebabkan VCO tidak dapat terlarut di dalam larutan DPPH (Wallace, 2018). Pengujian DPPH disarankan untuk menggunakan sampel uji yang dapat larut di dalam larutan DPPH sehingga dapat terjadi reaksi secara keseluruhan (Kedare and Sigh, 2012). Penelitian dengan sampel uji berupa minyak nabati khususnya VCO, umumnya dilakukan fraksinasi terlebih dahulu dengan pelarut polar sebelum dilakukan pengujian DPPH (Marina et al, 2009; Arlee et al, 2013; Valantina and Neelamegam, 2015). Oleh karena itu, pengujian aktivitas antioksidan VCO menggunakan fraksi metanolnya. Selain fraksi metanol VCO dan madu kele Bali, vitamin C sebagai pembanding dan variasi kombinasi fraksi metanol VCO dan madu kele Bali juga diuji aktivitas antioksidannya. Dengan menggunakan kurva hubungan konsentrasi sampel uji dengan persen inhibisi (\% IC) rata-rata terhadap DPPH ditentukan aktivitas antioksidannya berdasarkan nilai $\mathrm{IC}_{50}$. Nilai $\mathrm{IC}_{50}$ vitamin $\mathrm{C}$, fraksi metanol VCO, madu kele Bali, dan berbagai variasi kombinasi fraksi metanol VCO dan madu kele Bali dapat dilihat pada Gambar 2.

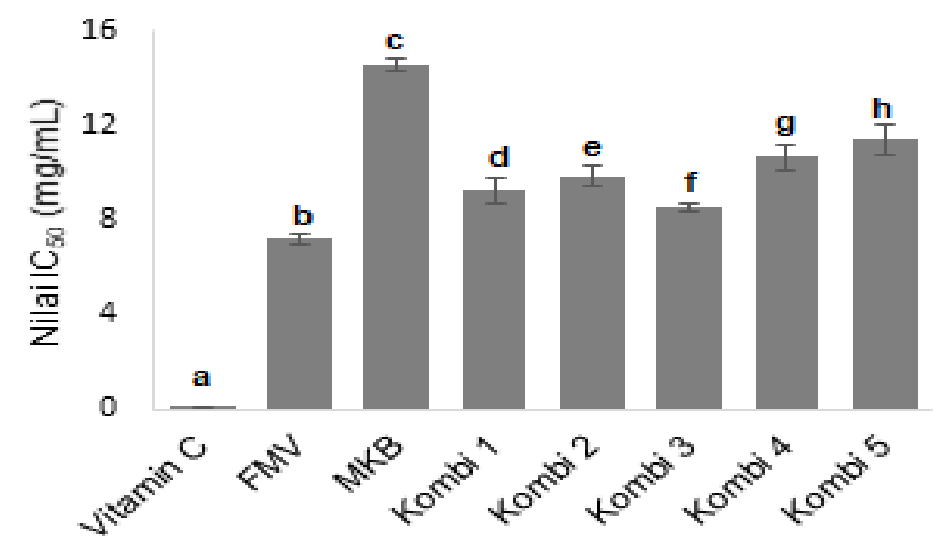

Gambar 2. Nilai $\mathrm{IC}_{50}$ vitamin $\mathrm{C}$, fraksi metanol VCO, madu kele Bali, dan berbagai variasi kombinasi fraksi metanol VCO dan madu kele Bali. Keterangan: Vit.C = vitamin $\mathrm{C} ; \mathrm{FMV}=$ fraksi metanol VCO; $\mathrm{MKB}=$ madu kele Bali; Kombi 1= Kombinasi 0,0105 g FMV dan 1 g MKB; Kombi 2= kombinasi 0,0084 g FMV dan 2 g MKB; Kombi 3= kombinasi 0,0063 g FMV dan 3 g MKB; Kombi 4= kombinasi 0,0042 g FMV dan 4 g MKB; Kombi 5= kombinasi 0,0021 g FMV dan 5 g MKB; Data yang ditampilkan adalah $\overline{\mathrm{x}} \pm \mathrm{SD}(\mathrm{n}=6)$; Huruf yang berbeda menandakan perbedaan yang bermakna $(\mathrm{p}<0,05)$.

Berdasarkan data pada Gambar 2 dapat dilihat bahwa seluruh sampel uji (fraksi metanol VCO, madu kele Bali, dan berbagai variasi kombinasi fraksi metanol VCO dan madu kele Bali) memiliki aktivitas antioksidan yang lebih lemah dan berbeda bermakna dibandingkan pembanding vitamin $\mathrm{C}(\mathrm{p}<0,05)$. Berdasarkan nilai $\mathrm{IC}_{50}$-nya, seluruh sampel uji dikatagorikan 
memiliki aktivitas antioksidan lemah dengan nilai $\mathrm{IC}_{50}>0,15 \mathrm{mg} / \mathrm{mL}$, sedangkan vitamin $\mathrm{C}$ dikatagorikan sebagai antioksidan kuat dengan nilai $\mathrm{IC}_{50}<0,05 \mathrm{mg} / \mathrm{mL}$ (Thamrin et al, 2016).

Perbandingan jumlah fraksi metanol VCO dan madu kele Bali dalam kombinasi memberikan pengaruh yang bermakna terhadap aktivitas antioksidannya $(p<0,05)$. Selain itu kombinasi kedua bahan tersebut memberikan aktivitas yang lebih kuat dan bermakna bila dibandingkan dengan penggunaan madu kele Bali tunggal, namun lebih lemah dibandingkan fraksi metanol VCO. Pada Gambar 2 juga tampak bahwa nilai $\mathrm{IC}_{50}$ semua kombinasi tidak memiliki hubungan linear terhadap jumlah penggunaan bahan. Semakin banyak jumlah penggunaan madu kele atau fraksi metanol di dalam campuran tidak menjamin memiliki nilai IC50 yang semakin rendah, melainkan penggunaan madu kele dan VCO yang sebanding (kombinasi 3) memiliki nilai IC $_{50}$ yang terendah dibandingkan semua kombinasi. Berdasarkan data tersebut, kombinasi 0,0063 g fraksi metanol VCO dan $3 \mathrm{~g}$ madu kele Bali memberikan aktivitas antioksidan terkuat bila dibandingkan kombinasi lainnya. Data ini dapat dijadikan bahan pertimbangan apabila hendak melakukan kombinasi sediaan topikal dengan bahan aktif madu kele Bali. Pada sediaan tersebut penambahan fraksi metanol VCO dengan perbandingan yang sesuai dapat meningkatkan aktvitas antioksidannya.

Aktivitas antioksidan dari fraksi metanol VCO, madu kele, dan kombinasi keduanya dapat dipengaruhi oleh senyawa fitokimia yang terkandung di dalamnya. Menurut Pulung (2016), kandungan polifenol (tanin dan flavonoid) yang terdapat di dalam fraksi polar (fraksi metanol) dapat bertindak sebagai akseptor radikal DPPH. Keberadaan senyawa tersebut berpengaruh terhadap aktivitas antioksidan yang kemudian berkorelasi dengan resistensi minyak terhadap oksidasi yang menyebabkan bau tengik (Mosca et al, 2000). Madu kele yang digunakan mengandung beberapa senyawa fitokimia yaitu saponin, fenol, flavonoid, dan steroid/triterpenoid. Golongan senyawa yang diduga kuat berpengaruh terhadap aktivitas antioksidan (peredaman radikal bebas) adalah senyawa fenol dan flavonoid. Gunawan et al (2018), melaporkan bahwa fraksi etil asetat dari madu lebah tanpa sengat memiliki aktivitas antioksidan lebih tinggi daripada fraksi n-heksana dan fraksi etanol. Diketahui bahwa fraksi etil asetat tersebut memiliki kandungan fenol dan flavonoid yang lebih tinggi. Hal ini diperkuat dengan hasil pengujian yang dilakukan Duarte et al (2012) dan Sumarlin et al (2015), bahwa terdapat hubungan aktivitas antioksidan madu lebah tanpa sengat dengan nilai kandungan fenol dan flavonoid yang terkandung di dalam madu. Senyawa fenol dan flavonoid berpengaruh pada aktivitas antioksidan melalui aktivitas scavenging dan pembentukan khelat (Sumarlin dkk., 2015). 
Flavonoid dapat meredam radikal bebas khususnya reactive oxygen species (ROS) dengan mendonorkan hidrogen ke radikal hidroksil ataupun peroksil. Flavonoid yang telah kehilangan atom hidrogennya relatif bersifat stabil sehingga rantai reaksi pembentukan radikal bebas dapat terputus (Pannala et al, 2001). Reaksi peredaman radikal bebas oleh fenol erat kaitannya dengan flavonoid. Flavonoid merupakan senyawa turunan fenol dengan struktur dasar berupa senyawa flavan (2-fenil-benzo-piron). Sehingga reaksi flavonoid terhadap radikal bebas dapat mewakili reaksi yang terjadi juga pada fenol terhadap radikal bebas (Leopoldini et al, 2011). Penelitian terkait senyawa golongan saponin dan triterpenoid pada madu dengan aktivitas antioksidan masih belum ada. Namun pada sampel uji bukan madu, senyawa golongan saponin dan triterpenoid dilaporkan memiliki aktivitas antioksidan (Cai et al, 2019; Nafiu and Ashafa, 2017). Salah satu senyawa saponin dilaporkan memiliki aktivitas penangkap radikal bebas dengan mekanisme yang sama seperti senyawa golongan flavonoid (Yoshiki and Okubo, 1995).

Kombinasi dua jenis bahan dapat mempengaruhi aktivitas antioksidan. Masing-masing bahan memiliki senyawa metabolit sekunder yang berpotensi saling berinteraksi apabila dikombinasikan. Senyawa-senyawa selain zat aktif sebagai komponen utama mungkin berpotensi mempengaruhi respon aktivitas antioksidan. Perbedaan aktivitas antioksidan ini diduga disebabkan distribusi jumlah dan jenis senyawa metabolit sekunder dengan sifat antioksidan yang terkandung di dalam sampel uji (Huliselan, dkk., 2015). Menurut Aftab and Vieira (2010), kombinasi senyawa fitokimia dapat meningkatkan aktivitas antioksidan melalui mekanisme regenerasi senyawa antioksidan yang telah tidak aktif. Ketika senyawa antioksidan telah mendonorkan protonnya untuk menstabilkan senyawa radikal, maka senyawa tersebut tidak aktif lagi sebagai antioksidan. Melalui kombinasi senyawa fitokimia, mekanisme regenerasi senyawa antioksidan dapat terjadi, walaupun aktivitas antioksidan dari salah satu bahan sangat rendah (Aftab and Vieira, 2010).

\section{Kesimpulan}

Fraksi metanol VCO, madu kele Bali, dan kombinasi keduanya dengan berbagai variasi perbandingan bobot memiliki aktivitas antioksidan lemah $\left(\mathrm{IC}_{50}>0,15 \mathrm{mg} / \mathrm{mL}\right)$. Variasi kombinasi fraksi metanol VCO dan madu kele Bali berpengaruh secara bermakna terhadap aktivitas antioksidannya $(\mathrm{p}<0,05)$, dimana kombinasi $0,0063 \mathrm{~g}$ fraksi metanol VCO dan $3 \mathrm{~g}$ madu kele Bali memberikan antivitas antioksidan terkuat dibandingkan kombinasi lainnya dengan nilai $\mathrm{IC}_{50}$ sebesar $8,50 \pm 0,17 \mathrm{mg} / \mathrm{mL}$. Pengujian aktivitas antioksidan pada penelitian ini hanya dilakukan dengan dengan satu metode yaitu metode DPPH, sehingga diharapkan pada 
penelitian selanjutnya dapat dilakukan metode pengujian yang lain agar kapasitas total antioksidan dapat diketahui.

\section{Ucapan Terimakasih}

Ucapan terima disampaikan kepada Fakultas MIPA Universitas Udayana yang telah memberikan bantuan dana melalui Hibah Penelitian Unggulan Program Studi tahun 2020.

\section{Deklarasi Konflik Kepentingan}

Semua penulis menyatakan tidak ada konflik kepentingan terhadap naskah ini.

\section{Daftar Pustaka}

Aftab, N. and Vieira, A. (2010). Antioxidant Activities of Curcumin and Combinations of this Curcuminoid with other Phytochemicals. Phytotherapy Research, 24:500-502.

Arlee, R., Suanphairoch, S. and Pakdeechanuan, P. (2013). Differences in Chemical Components and Antioxidant-related Substances in Virgin Coconut Oil from Coconut Hybrids and Their Parents. Internasional Food Research Journal, 20:2103-2109.

Cai, C., Ma, J., Han, C., Jin, Y., Zhao, G., and He, X. (2019). Extraction and Antioxidant Activity of Total Triterpenoids in The Mycelium of A Medicinal Fungus. Sanghuangporus sanghuang, Scientific Reports, 9: 7418.

Chan, B.K., Haron, H., Talib, R.A. and Subramaniam, P. (2017). Physical Properties, Antioxidant Content and Anti-Oxidative Activities of Malaysian Stingless Kelulut (Trigona spp.) Honey. Journal of Agricultural Science, 9:32.

Chayati, I. dan Miladiyah, I. (2014). Kandungan Komponen Fenolat, Kadar Fenolat Total, dan Aktivitas Antioksidan Madu dari Beberapa Daerah di Jawa dan Sumatera. Media Gizi Mikro Indonesia, 6:11-24.

Depkes RI. (1989). Materia Medika Indonesia, Edisi V, Jakarta. Departemen Kesehatan Republik Indonesia.

Depkes RI. (1995). Materia Medika Indonesia, Edisi VI, Jakarta. Departemen Kesehatan Republik Indonesia.

Diba, F., Hastuti, D. dan Jumari. (2018). Kelapa Sebagai Komponen Bahan Ramuan Obat di Karaton Ngayogyakarta Hadiningrat dan Pura Pakualaman. Jurnal Penelitian dan Pengembangan Pelayanan Kesehatan, 2:23-28.

Duarte, A.W.F., Vasconcelos, M.R.D.S., Menezes, A.P.D., Silva, S.C., Oda-souza, M., and Lopez, A.M.Q. (2012). Composition and antioxidant activity of Honey from Africanized and Stingless Bees in Alagoas (Brazil): A Multivariate Analysis. Journal of Apicultural Research, 51:23-35

Eder, E., Wacker, M., Lutz, U., Nair, J., Fang, X., Bartsch, H., Beland, F.A., Schlatter, J., Lutz, W.K. (2006). Oxidative Stress Related DNA Adducts in the Liver of Female Rats Fed with Sunflower, Rapeseed, Olive or Coconut Oil Supplemented Diets. Chemicobiological interactions, 159:81-89.

Gandjar, I.B. dan Rohman, A., 2012, Analisis Obat Secara Spektrofotometri dan Kromatografi, Pustaka Pelajar, Yogyakarta, Indonesia.

Gunawan, R., Erwin, dan Syafrizal. (2018) Uji Fitokimia dan Penentuan Aktivitas Antioksidan dari Madu Trigona incisa. Jurnal Atomik, 3:18-21.

Harborne, J.B. (1987). Metode Fitokimia: Penuntun Cara Modern Menganalisa Tumbuhan. Bandung, Penerbit ITB.

Harningsih, T. dan Wimpy. (2018). Uji Aktivitas Antioksidan Kombinasi Ekstrak Daun Kersen (Muntigia calabura Linn.) dan Daun Sirsak (Anonna muricata Linn.) Metode DPPH 
(2,2-difenil-1-pikrilhidrazil). Biomedika, 11:70-75.

Huliselan, Y. M., Runtuwene, M. R. J., dan Wewengkang, D. S. (2015). Aktivitas Antioksidan Ekstrak Etanol, Etil Asetat, dan n-Heksan dari Daun Sesewanua (Clerodendron squamatum Vahl.). PHARMACON Jurnal Ilmiah Farmasi-UNSRAT, 4:155-163.

Kedare, S.B. and Singh, R.P. (2012). Genesis and Development of DPPH Method of Antioxidant Assay. Journal Food Science Technology, 48:412-422.

Kek, S.P., Chin, N.L., Yusof, Y.A., Tan, S.W. and Chua, L.S. (2014) Total Phenolic Contents and Colour Intensity of Malaysian Honeys from the Apis spp. and Trigona spp. Bees. Agriculture and Agricultural Science Procedia, 2:150-155.

Leopoldini, M., Russo, N., and Toscano, M. (2011). The Molecular Basis of Working Mechanism of Natural Polyphenolic Antioxidants. Food Chemistry, 125:288-306.

Lukitaningsih, E. (2009). 'The Exploration of Whitening and Sun Screening Compounds in Bengkoang Roots (Pachyrhizus erosus)'.Disertasi, Dr., Universität Würzburg, Würzburg.

Malik, N.A., Mohamed, M. and Mustafa, M.Z. (2019). In Vitro Modulation of Extracellular matrix genes by stingless bee honey in cellular aging of human dermal fibroblast cells. Journal of Food Chemistry, 1-8.

Marina, A.M., Man, Y.B.C., Nazimah, S.A.H. and Amin, I. (2009) Antioxidant capacity and phenolic acids of virgin coconut oil. International Journal of Food Sciences and Nutrition, 60:114-123

Martin, A., Swarbrick, J., dan Cammarata, A. (1993). Dasar-Dasar Farmasi Fisik Dalam Ilmu Farmasetik, Edisi III (Terjemahan). Jakarta, UI Press.

Molyneux, P. (2004). The Use of The Stable Free Radical Diphenylpicryl-hydrazyl (DPPH) for Estimating Antioxidant Activity. Songklanakarin Journal Science Technology, 26:211219.

Mosca, L., Marco, C.D., Visioli, F., and Cannela, C. (2000). Enzymatic Assay for the Determination of Olive Oil Polyphenol Content: Assay Conditions and Validation of the Method. Journal Agricultur Food Chemical, 48:297-301.

Nafiu, M.O. and Ashafa, A.O.T. (2017). Antioxidant and Inhibitory Effects of Saponin Extracts from Dianthus basuticus Burtt Davy on Key Enzymes Implicated In Type 2 Diabetes In vitro. Pharmacognosy Magagazine, 13:576-82

Nevin, K.G. and Rajamohan, T. (2004). Beneficial effects of Virgin Coconut Oil on Lipid Parameters and in vitro LDL oxidation. Clinical Biohemistry, 37:830-835

Novarianto, H. dan Tulalo, M. (2007). Kandungan Asam Laurat pada Berbagai Varietas Kelapa Sebagai Bahan Baku VCO. Jurnal Littri, 13:28-33.

Pannala, A.S., Chan, T.S., O’Brien, P.J, and Rice-Evans, C.A. (2001). Flavonoid B-Ring Chemsistry and Antioxidant Activity: Fast Reaction Kinetics. Biochemical and Biophysical Research Communications, 282:1161-1168.

Parwata, I.M.O.A., Ratnayani, K., dan Listya, A. (2010) Aktivitas Antiradikal Bebas serta Kadar Beta Karoten pada Madu Randu (Ceiba pentandra) dan Madu Kelengkeng (Nephelium longata L.). Jurnal Kimia, 4:54-62.

Pulung, M.L., Yogaswara, R. dan Sianipar, F.R.D.N. (2016). Potensi Antioksidan dan Antibakteri Virgin Coconut Oil dari Tanaman Kelapa Asal Papua. Chemistry Progress, 9:75-82.

Robinson, T. (1991). Kandungan Organik Tumbuhan Tingkat Tinggi. Bandung, Penerbit ITB.

Rozi, F. Abram, P.H., dan Diah, A.W.M. (2018). Pengaruh Kombinasi dan Rasio Pelarut terhadap Hasil Ekstraksi Minyak dari Serabut Kelapa Sawit. Jurnal Akademika Kimia, 7:146-151.

Sari, N., Wahidah, B.F. dan Gaffar, N.A. (2017). 'Etnobotani tumbuhan yang digunakan dalam pengobatan tradisional di kecamatan Sinjai Selatan kabupaten Sinjai Sulawesi Selatan', 
Prosiding Seminar Nasional Biology for Life (pp 6-13). Makasar, Jurusan Biologi Fakultas Sains dan Teknologi UIN Alauddin.

Setiaji, B. dan Prayugo, S. (2006). Membuat VCO Berkualitas Tinggi, Penebar Swadaya, Jakarta.

Sumarlin, O.L., Suprayogi, A., Rahminiwati, M., Tjachja, A. dan Sukandar, D. (2015). Bioaktivitas Ekstrak Metanol Daun Namnam serta Kombinasinya dengan Madu Trigona. Jurnal Teknologi dan Industri Pangan, 26:144-154

Thamrin, A., Erwin, dan Syafrizal. (2016). Uji Fitokimia, Toksisitas Serta Antioksidan Ekstrak Propolis Pembungkus Madu Lebah Trigona Incisa dengan Metode 2,2-diphenyl-1picrylhidrazyl (DPPH). Jurnal Kimia Mulawarman, 14:54-60.

Valantina, R.S and Neelamegam P. (2015). Selective ABTS and DPPH radical scavenging activity of peroxide from vegetable oils. Internasional Food Research Journal, 22:289294.

Wallace, T.C. (2018). Health Effects of Coconut Oil-A Narrative Review of Current Evidence. Journal of The American College of Nutrition, 38:97-107.

Wicaksono, I.B. dan Ulfah, M. (2017). Uji Aktivitas Antioksidan dan Kombinasi Ekstrak Etanol Daun Sirsak (Annona mucirata L.) dan Daun Jambu Biji (Psidium guajava L.) dengan metode DPPH (2,2-difenil-1-pikrilhidrazil). Inovasi Teknik Kimia, 2:44-48.

Winarsi, H. (2007). Antioksidan Alami dan Radikal Bebas, Yogyakarta, Kanisius.

Yoshiki, Y. and Okubo, K. (1995). Active Oxygen Scavenging Activityof DDMP (2,3-Dihydro2,5-dihydroxy-6-methyl-4H-pyran-4-one) Saponin in Soybean Seed. Biosciense, Biosciense Biotechnology and Biochemistry, 59:1556-1557.

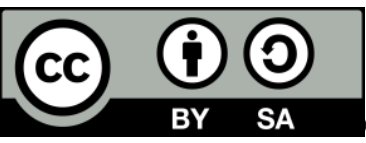

2020 by the authors. Submitted for possible open access publication under the terms and conditions of the Creative Commons Attribution-ShareAlike 4.0 International (CC BY-SA 4.0) license (https://creativecommons.org/licenses/by-sa/4.0/). 